\title{
Football Talent-Nurture \\ after the 1989-1990 Political \\ Transformation in Hungary
}

\author{
Vincze Géza
}

Semmelweis University, Budapest, Hungary

KEYWORDS

Hungarian football used to be in the first line of the international arena but for the last five decades a steady and strong setback has been a characteristic feature. The main purpose of this paper is to discover the major problems related to the education of young players and to make suggestions to improve the current situation. The study is based on a research in which three different but complementary methods, called "triangulation" were used: fieldwork, content analysis and in-depth interviews. The results show that although sport had always been the area which served political interests, this situation has dramatically changed after 1989-1990. Since then moral and economic crisis could be observed and this has resulted in the collapse of the Hungarian football. Concerning the talent care program there is no a common educational project for young players. This could be explained by the lack of cooperation between professionals who believe that they have different professional and financial interests and act accordingly. In conclusion it can be stated that success could only be reached if politics and the central budget were be independent and the cooperation between decision makers and experts in football were stronger. The unskilled managers and coaches responsible for the education of young players should be exchanged for real professionals.

education, qualitative methods, junior players, financing

\section{Introduction}

The topic of this study is strictly connected to those scientific studies which were to demonstrate the social and political changes after the collapse of the old regime (Andorka 1996, Kovách 2002, Szalai 1992, 1994). Specifically these papers discover the changes in the structure of the government and their characteristic features socially in the post-socialist countries. According to Földesiné (1996 a), investigating the social changes is a relatively weak and new-born field of sociology, therefore no comprehensive theory or study has been made so far. Furthermore it is generally agreed that the sport-society-politics connection is worth undergoing any kind of scientific research (Földesiné 2003).

The first studies about the changes and characteristics of the socialist sporting icon were published in Poland (Krawczyk 1992, 1996). On the other hand in Hungary only a small amount of 
studies were conducted, analyzing parts of the economical and political changes and their effects on sport (Földesiné 1993, 1996c, Frenkl 2003, Laki and Nyerges 2006, Takács 1996). It is worth noting that football was out of the fringe of these analyses.

There is no doubt that football is one of the most popular sports (Luxbacher 1996), besides, it can be said that it is a sport where complete international cooperation does exist (Chyzowych 1982). Additionally, this branch of sport is a popular subject for the field of sport sciences, but mostly tactics and techniques have been analyzed so far (Lees and Nolan 1998, Levanon and Dapena 1998, Maguire and Stead 1998). On the other hand research has been particularly interested in the professional players, but there is hardly any academic research and study concerning the education of young players (Gil et al. 2007a). Also, there are very few empirical studies focusing on the improvement of young talents and the joint effect of human and non-personnel factors (Gil et al. 2007b).

For the last several decades Hungarian football has started to lose its popularity and success within society. The great depression of efficiency and standards has given me reason to start searching for solutions to the current situation. My further aim is to help to put Hungarian football back at the forefront.

Those who are interested in football might have heard about a possible solution suggesting that the decline of football could only be stopped by systematically improving the education of young players. Hungarian football used to be at the forefront of the national teams, but for the last five decades a steady and strong setback has been a characteristic feature (Szegedi 2003).

\section{Objectives}

The main purpose of my study is to find out the problems in the education of young players and to make suggestions for improving the current situation and stopping this devastating process. With the study I intend to analyze and represent those changes in the domain of football, which occurred after the collapse of the old political regime. Furthermore this study analyzes and compares the results and difficulties in a complex manner.

I was driven by personal interest when I chose the topic, because I have been involved in this sport for nearly three decades and have taken an active part in almost every field of it. Because of the fact that the questions in my study are multifaceted and there are hardly any people who have dealt with cause and effect analysis with this issue so far, I intend to analyze those factors, with which the problematic area can be discovered and understood.

In my discourse I have tried to demonstrate those factors and elements with which the improvement of the education of young football players could be realized. I consider the education of young players in the past and in the present as the discovery of structures, motives, and such methods used in the characteristics and interests of the affected people. What's more, I would like to draw those complex tasks and supportive structures which can put Hungarian football at the cutting edge of European football in a relatively short time.

During the years spent in this sport and based on the previous studies the following questions have been raised:

1. What are those characteristics which can be discovered in the domain of Hungarian sport, especially in football after the collapse of the regime?

2. Based on sport professionals what is the effect of the collapse of the old political regime on the education of young players and how is it realized? 
3. How do the educational systems work, which were established in order to support the young players in theory and in practice?

4. What are the experiences of sport professionals concerning the present situation of football and how can be the situation of young talents be improved?

5. What are the possibilities for football to become more socially accepted?

Based on the questions the hypotheses are the following:

1. After the collapse of the old regime organizations in charge of judgment tended to subordinate the sport and football issues to their own political interests in Hungary;

2. The clubs, which are to educate young football players, with federal budget is replaced to institutes, do not want to or are unable to provide an appropriate financial-professional background in this cruel financial race;

3. Those educational systems which were established on behalf of the education of young players are working successfully and independently, but because of the lack of cooperation and trust their effectiveness is diminishing. Furthermore practice and theory are not in tune with each other;

4. Illustrious agents of football all agree about the importance of cooperation and the establishment of clear circumstances; furthermore they tend to emphasize particularly the role of schools in the improvement of the education of young players;

5. If the decision-making process, which is needed for the education of young players, concerning football involved the cooperation of these illustrious agents, then this branch of sport would definitely be much improved and its social appreciation would grow.

\section{Materials and Methods}

In my research I have bound together three different but complementary methods. This process is called "triangulation" in research methodology (Giddens 2003). These methods are fieldwork, content analysis and in-depth interviews. It is important to note the fact of the permanent practicetheory balance, how they are built up around each other and their interpretation of a higher level (Thomas and Nelson 1996). In my study the qualitative data analysis has gained a great emphasis, too.

\section{Fieldwork}

During fieldwork the observation and analysis are woven into each other (Giddens 2003), and the organization and construction of the analytical part of Bogdewick's suggestions (1992) were helpful. As an observational participant I either was or now am currently living together with football and am directly participating in it. During the last three decades I have managed to understand football on its own, see its mechanism and understand its connections. I have not simply just been a participant, but have been working for the football community by gathering data and analyzing the state of young football players. My activity has been driven by good intent, so the football community accepted and appreciated my work. Thanks to the fieldwork I have managed to gain such information which is unique, because you cannot find it in any documents or interviews. The method has given me the chance to observe coaches and leaders in real-life situations: during training, during half-term breaks and in various meetings. 


\section{Content analysis}

I have conducted the inductive content analysis based on the directives of Patton (1990), Becker (1998), Maykut and Morehouse (1994). Furthermore after the collapse of the old regime the written documents - mainly the public and private ones - have been systematically analyzed in my research too. Among the huge amount of written documents issued by football's leading institutes there were some which provided crucial resources. They contained statutes, reports and the extracts of the committee sessions, which were used and analyzed in my study.

\section{In-depth interview}

In favour of answering the questions the suggestions of Miles and Huberman (1994) seem to be useful, and based on these suggestions I have conducted one-and-half-hours of in-depth interviews with the illustrious personalities of football, who - in my view - have indispensable information about the current situation of football. The interviews were designed based on the research strategy of Szabolcs (2001) and I was intent on comprehending and understanding the topic. During the in-depth interviews I followed the suggestions and guidlines of Creswell (1997) and I did not hide my own personal experiences, so the interviews were mainly chats, talks and common solution seeking.

The most crucial aspect of choosing the pattern is to deal with professionals of this branch of sport. So the pattern $(\mathrm{N}=17)$ was chosen based on these:

1. All the nine determining professionals (each of them coaches in the Hungarian Premier League, former head coaches of the Hungarian national team);

2. Five men who were and are the MLSZ chairmen, who were dominant characters in the improvement of football;

3. Three living legends of football (Szepesi György, Buzánszky Jenő and Albert Flórián).

\section{Results}

The effect of the new regime on sports and the characteristics in the education of young players

After the collapse of the old regime the governing parties were unable to adopt a groundbreaking change in sport policy; they just assumed the idea of federal governance. But since the outset this governance has always been in a one-sided fight with the self-governance of the sport professionals, whose work finally became successful in 1996 when a sport law was born. Unfortunately no satisfactory financial background has been established to it.

Even an independent ministry of sport and its assigns could not improve the situation. What's more, it preserved some unbeneficial mechanisms and unfavourable actualities in the domain of sport in Hungary. By waiving the debts the situation of clubs and the fragile morale have deteriorated, which confirm that false statement that the government can't resist giving a helping hand in the case of trouble. So there is a great concern among sport leaders about the possibility of getting into the state's good books.

After the collapse of the old regime there was still no education of football players within the framework of special schools, and the basic elements of this branch of sport are hardly coached. What experience shows is that games masters are excluded from the issue by the system and framework of the education of young football players, because it supports pro licence instead of training and courses backed up by the government so it places education out of schools. Therefore games masters are not able to encourage their students to pursue football, and consequently they head towards other fields 
and train players from other these branches. During the interviews it is revealed that experts prefer the help of dormitories, and not in academic terms.

Concerning the support for the education of young players in first-line teams, the gap is huge. For a spectator these clubs - without any exaggeration - are considered as a place which swallows money; there is a lot of abuse and the local governments with serious financial problems are eager to avoid them.

According to the experience of sport leaders it is a general fact that the money transferred by local governments is swallowed by the budget of the clubs, so junior and student sport could not receive any financial support. Therefore it is no coincidence that there is an independent financial unit for dealing with young football players and a growing possibility that the local governments will grant financial help. Additionally the local government would rather pay in kind to the clubs, but this will not work in the long term. The interviews showed that the situation of the education of young players in the hierarchy of bigger clubs is extremely tough. In many cases the education of young players is not structurally and financially independent of these clubs, which mainly deal with professional teams of adults. Consequently the structure of these clubs makes it harder to draw in and utilize external monetary resources.

The independent training clubs for young football players are in an even worse situation. These small clubs are trying to be more successful on the financial side, and therefore the local powers consider them to be a and they do not receive any support.

\section{The theory and practice of young players in the domain of football}

The education of young players is a structural part of football so it is part of the sport as of a subsystem. The Hungarian sport community was not ready for a new regime because the conception and the solutions were missing. This situation had a significantly bad effect on the education of young players. The professional adult teams were supported - more or less - by politics at local and national level, but the situation of young players did not receive much support politically. Therefore problems occurred with dramatic rapidness, and the solutions to them remained at individual level, which affected coaches.

The new regime basically swallowed the old system of education of young players, but it did not include much of the new one. The state naturally is either unable or not in a position to file out from the field of the education of young players; soon it is bound to find cooperative partners who manage to support it with external sources.

Hungarian football was relatively popular in the 1980s - think of the participation in the World Cups of 1982 and 1986 with the superstars. This was considered an opportunity to improve the education of young players and to make them more successful. Therefore external investors appeared in the field of the education of young players, and they compiled various and numerous ideas.

Professionals consider the following points as essential for the sake of improving the education of young talented players:

1. Well-trained and skilful games masters should have the responsibility to make students devoted to football. Bringing students aged between 6 and 13 out of the framework of schools and get them into football clubs cannot be considered to be a good solution. It is important to note that within the framework of schools every child should receive the right to acquire the basics of a sport, to realize his or her talent and skills and to practise. Briefly, football should be returned to elementary schools, where its hard core should be reorganized and established to 
rebuild its popularity. Additionally kindergartens should be taken into account.

2. In selecting young football players, schools play a significant role, and we can separate those who play football as a hobby without any effort. The training of players should predominantly be the responsibility of clubs; talented people should be involved in such training at the age of 13 or 14 because clubs provide a financial and material background.

3. Periodical financial resources have been used inappropriately and with low efficiency. For example, if there were some kind of financial support, firstly a country-wide system was established so the competition and education of young football players received less and less financial support. The Bozsik Programme and Goliat FC McDonald's are examples for the fact that even though there is some financial support in the system, it does not guarantee success.

4. Associations - essentially for the clubs of the Hungarian Premiere League. As an example, the MLSZ performs several tasks, although it is unable to provide enough resources for them. Furthermore it is also a huge problem that the MLSZ expects of clubs the continuous training of young players, while it preaches that the talented people should be taken out of the education system because of the training of all-Hungarian teams of certain age-groups. So there is a great opportunity to disclaim all responsibility if a team is proved to be unsuccessful.

5. The effective system of coach training should be accommodated, which would contain the practical training (conduct of training, training attendance), the moral and financial appreciation of this profession, the qualitative education of young players, and the conformance to demands concerning those coaches who are working with adults.

6. Management, marketing and promotion should actively take part in the domain of the education of young players. Financial issues and the sphere of action should be clarified, and the relationship between coaches and managers could thereby be improved.

In favour of realising all these points, the following tasks and possibilities are required, based on the point of view of professionals and the written documents mentioned earlier.

1. Establishing a nation-wide structural framework, to which the financial background would be provided by the government, and creating a modern educational program which would provide a federal educational programme for young players.

2. Establishing a special football school involving professionals, whereby parents would pay certain, considerable fees and the operating costs of this institute would be provided without reimbursement by the cooperative members - such as local authorities, the state, clubs etc. who would therefore be without most of the costs concerning the education of young players. Furthermore the the selling of the players would defray the remaining expenses. This situation presupposes the presence and need of sponsors and investors.

3. Establishing such an educational programme for young players, which would be supported financially by several sponsors. What's more, parents would contribute to defraying the expenses, and therefore they would be able to identify any aims, which are socially accepted and constitute a social initiative.

4. Establishing clubs representing the Western European pattern, which still operate by selling the players. This is purely about business where a financial or professional investor risks his assets for the sake of the forthcoming profit in the future. 


\section{Discussion}

The present educational system for young players should not and might not be supplemented here and there, because the low number of "employees" does not allow it. There is no point in wasting too much time with the efficiency of the system. It is advisable to turn back to the successful model and to make an attempt to find its up-to-date alternative. The main stream in this process is to revive a wide base. This means that we should include schools because there are no free places for that purpose. This is partly the task of management too.

Talented young footballers should be brought into clubs, which is party the task of managers and professionals, because the selection is definitely a task for professionals while the education and performance in competition are partly the task of professionals and management. The education of young players in schools and clubs should be a balance to support and strengthen each other. This is particularly inevitable in the case of students aged 14-17.

It would be better if the cooperation between local, area and regional authorities were realized, and the corporations should be coordinators and organizers, which is mostly the task of managers.

To do this, coaches - manager-like characters - of young players should be trained and provided with enough space. This would involve a sufficient salary, which has two elements. Coaches are given a certain amount of money as a monthly salary, and they would be given a bonus for each player if these players joined an adult team or were sold to a club. The coaches will thus be interested in the appropriate training of young players and become more attentive because it is their duty and they are supported financially. Furthermore this is connected to the topic of improving the financial appreciation of games masters in elementary schools. To do this after players have become members of a professional team, he or she should be given some financial support or remuneration.

Treating young reserves as superstars should be averted or stopped because it is unnecessary in their educational and competitive system. But this does not mean that the various types of camps should be banned. It simply does not make the system of training and competitions of that age group because it would have significant and serious consequences in the future. Therefore the responsibility of clubs should be restored for the sake of improving the level, professional background and efficiency.

In the domain of professional training there are urgent issues such as adopting reforms, abolishing the opposition between technical and pro licence coaches; because only the results count for a professional, not the number of diplomas, the grade or its addressor. It should be achieved that everybody has pro licence or be a technical coach in the Hungarian Premier League, which means that everybody can achieve the grade that they do not yet possess. The crucial factor of the professional headway is a comprehensive and well-matching system, whose coordinator is the Hungarian Football Association (MLSZ). It goes pari passu with institutes of higher education, which are responsible for training sports professionals and PE teachers. The main centre for this training should be established where the best professional, intellectual and infrastructural background is situated. It is needed for joining the Bologna educational programme, and the education of young players could be easily fitted into this system because the much-needed body of information would be provided at the right time and in a good quantity, so it will not come as a bolt from the blue.

It is highly important to note that leaders, managers and promoters of the football community in Hungary - such as the executive board of the Hungarian Football Association, the county associations and the leaders of the clubs - should be the representatives on this issue.

For the sake of the appropriate training, preparation, performance of competitions for young 
talents, it would be sufficient for the liable clubs to create a system of elementary schools, high schools, amateur and second-class teams. Their main aim would be to choose, to have this age group between 14 and 18 - perform in competitions.

\section{Conclusions}

In conclusion it can be stated that the research produced both expected and unexpected findings in the following way:

The first hypothesis - supposing that sport is dependent on political interests - was admitted based on the analysis of documents and the people interviewed. Since the collapse of the old regime there has not been a commonly supported and accepted concept on this issue, except for the so-called "Strategy of Sport", which was accepted in 2008. Although sport has always been an area which served political interests, this situation has dramatically changed after 1989/1990. Since then, demanding financial and economical interests have occurred and this has resulted in the collapse of Hungarian football.

My second hypothesis was also admitted, and was supported by the statements derived from the analysis of documents, by the opinion of professionals: there is no common, existing educational programme for young players. That is because if such programme or effort were established, its educational and professional operation would not be enabled because of financial interests.

The first condition of my third hypothesis was not admitted because, based on the practical examples, it would be concluded that there is no any independent educational programme which could serve the interests of this branch of sport. Considering the causes, the second half of the hypothesis was admitted, which was considered and explained by the professionals as the lack of cooperation. These professionals and illustrious people from the world of football highlighted the low level of professional standards and exaction, so it is straightforward that the theory and practice are not in accordance with each other.

This means the admission of the fourth hypothesis too, because the concurrent and supported opinion of those most directly affected includes operative developmental suggestions for the sake of this sport. These suggestions focus on creating clear actuality. Furthermore, it would be rewarding to include these suggestions more effectively in the questions of the education of young players, in establishing conceptions and in establishing cooperation between branches of sports. The participants in the research considered the schools as having priority in this issue, while the critics considered them crucially important in improving the education of young players. According to their point of view, the coach training, the Hungarian Association of Olympics and the MLSZ should gain significant importance as well. It is clear that only schools are able to provide a greater amount and wide range of choice for young players.

My fifth hypothesis could also be admitted, because the success could only be achieved with the cooperation of a professional direction of affairs. We can only trust in the future development of Hungarian football if politics and the central budget were to be independent, and if the unskilled managers and coaches of the education of young players were exchanged for professionalism. It is sufficient because it would raise the level of social appreciation of football. 


\section{REFERENCES}

Andorka, R. (1996). A társadalmi integráció gyenge kötései - rendszerátalakulás Magyarországon. Századvég, 1, pp. 5-18.

Becker, H. S. (1998). Tricks of the trade - how to think about your research while doing it. Chicago: The University of Chicago Press.

Bogdewick, S. P. (1992). Participant Observation in Doing Qualitative Research. Research Methods for Primary Care. Vol. 3. London: Sage Publicatios.

Chyzowych, W. (1982). The World Cup. Icarus Press.

Creswell, W.K. (1997). Qualitative inquiry and research design. Choosing among five traditions. Thousand Oaks, London: Sage Publications.

Földesiné, Sz. Gy. (1996a). Sport policy in Hungary. In Chalip, L., Johnson, A., Stachura, L. (Eds.) National Sports Policies. An International Handbook. Connecticut - London: Greenwood Press, Westport, pp. 187-211.

Földesiné, Sz. Gy. (1996c). A magyar sport átalakulása az 1989-1990-es rendszerváltás után. In Földesiné Sz.Gy. (Szerk.) A magyar sport szellemi körképe 1990-1995. Budapest: OTSH-MOB, pp. 13-52.

Földesiné, Sz. Gy. (2003). Európai integráció: Nyertesek és vesztesek a sportban. Magyar Sporttudományi Szemle, 3, pp. 17-21.

Frenkl, R. (2003). Rendszerváltás a magyar sportban. In Frenkl Róbert: A TF és a magyar sport belülröl. Fair Play Sport. Budapest, pp. 53-59.

Giddens, A. (2003). Szociológia. Budapest: Osiris Kiadó.

Gil, S., Ruiz, F., Irazusta, A., Gil, J., Irazusta, J. (2007a). Selection of young soccer players in terms of anthropometric and physiological factors. Journal of Sport Medicine and Physical Fitness, 47, pp. 25-32.

Gil, S. M., Gil, J., Ruiz, F., Irazusta, A., Irazusta, J. (2007b). Physiological and anthropometric characteristics of young soccer players according to their playing position: rekevance for the selection process. Journal of Strength and Conditioning Research, 2, pp. 438-445.

Kovách, I. (Szerk.) (2002). Hatalom és társadalmi változás. A posztszocializmus vége. Budapest: Napvilág Kiadó.

Krawczyk, Z. (1992). Sport in the Era of Structural Changes: The Example of Eastern Europe. International Review for the Sociology of Sport, 1, pp. 89-97.

Krawczyk, Z. (1996). Image of Sport in Eastern Europe. Journal of Comparative Physical Education, 1, pp. 211.

Laki, L., Nyerges, M. (2006). Politika és élsport. Társadalomkutatás, 4, pp. 493-513.

Lees, A., Nolan, L. (1998). The biomechanics of soccer. A review. Journal of Sport Sciences, 16, pp. 211-234.

Levanon, J., Dapena, J. (1998). Comparison of the kinematic of the full-instep and pass kicks in soccer. Medicine Sciences in Sport and Exercise, 30(6), pp. 917-926.

Luxbacher, J. (1996). Soccer: Steps to success. Champaign, IL.: Human Kinetics.

Maguire, J., Stead, D. (1998). Border Crossings. Soccer labour migration and the European Union. International Review for the Sociology of Sport, 33(1), pp. 59-73.

Maykut, P., Morehouse, R. (1994). Beginning qualitative research: A philosophical and practical guide. London: Falmer Press.

Miles, M.B., Huberman, A.M. (1994). Qualitative data analysis: A sourcebook of new methods. Newbury Park, CA: Sage.

Patton, M. Q. (1990). Qualitative Evaluation and Research Methods. London: Sage Publications, Newsbury Park.

Szabolcs, É. (2001). Kvalitatív kutatási metodológia a pedagógiában. Budapest: Műszaki Könyvkiadó.

Szalai, E. (1992). Szociálpolitikai dilemmák. In Gyekiczky A. (Szerk.) A váltás rendszere. Tanulmányok a kormány politikájáról. Budapest: Politikai Tanulmányok Intézete Alapítvány. 
Szalai, E. (1994). A civil társadalomtól a politikai társadalom felé. Munkástanácsok 1989-1993. Budapest: TTwins Kiadó.

Szegedi, P. (2003). Az utánpótlás-nevelés a magyar labdarúgás struktúrájában. Budapest: Századvég.

Takács, F. (1996). Testkultúránk aktuális szociológiai problémái a rendszerváltozás után. In Földesiné Sz.Gy. (Szerk.) A magyar sport szellemi körképe 1990-1995. Budapest: OTSH-MOB, pp. 53-67.

Thomas, J. R., Nelson, J. K. (1996). Research methods in physical activity. (3 ${ }^{\text {rd }}$ ed.) Champaign, IL.: Human Kinetics. 